\title{
A Simple and Objective Carbon Footprint Analysis for Alternative Transportation Technologies
}

\author{
R. A. Dunlap ${ }^{1}$ \\ ${ }^{1}$ Department of Physics and Atmospheric Science, Dalhousie University, Halifax, Nova Scotia, Canada \\ Correspondence: R. A. Dunlap, Department of Physics and Atmospheric Science, Dalhousie University, Halifax, \\ Nova Scotia B3H 4R2, Canada. E-mail: dunlap@fizz.phys.dal.ca
}

Received: November 21, 2012 Accepted: December 17, 2012 Online Published: December 27, 2012

doi:10.5539/eer.v3n1p33 URL: http://dx.doi.org/10.5539/eer.v3n1p33

\begin{abstract}
A simple and straightforward method of analyzing the net carbon dioxide emissions that result from different alternative transportation technologies is presented. Results are shown for three different non-fossil fuel transportation technologies; battery electric vehicles, hydrogen fuel cell vehicles and hydrogen internal combustion vehicles. These results are compared with the carbon emissions of a traditional gasoline powered internal combustion engine vehicle. Battery electric vehicles are shown to have a significantly lower carbon footprint than gasoline vehicles. Fuel cell vehicles are comparable to gasoline vehicles while hydrogen internal combustion vehicles produce substantially more carbon dioxide. The importance of electricity generating infrastructure is discussed.
\end{abstract}

Keywords: carbon dioxide emissions, greenhouse gases, battery electric vehicles, fuel cell vehicles, hydrogen vehicles

\section{Introduction}

The development of non-fossil fuel based energy technologies is one of most important and difficult tasks facing humanity. Energy sources for transportation applications are a particularly challenging aspect of establishing a carbon-free energy economy for the future as they must be portable and robust. A consideration of the relevant criteria for some alternative transportation energy technologies has been presented in (e.g., Kraushaar \& Ristinen, 1993; Kruger, 2006; Vanek \& Albright, 2008). Suitable transportation technologies for widespread implementation must provide environmental advantages over traditional fossil fuel technologies, specifically with regard to total $\mathrm{CO}_{2}$ emissions, that is, their carbon footprint. A detailed and complete $\mathrm{CO}_{2}$ emission analysis is generally complex (see e.g. Korchinski, 2007) and must include a lifecycle analysis of all materials and involved. For this reason, a direct comparison of the different available transportation energy technologies is difficult. As well, economic considerations are important in determining viability of various technologies. Net efficiency is a critical factor in determining cost and while certain technologies may have minimal environmental impact, the efficiency is unacceptably low (e.g. hydrogen internal combustion vehicles, as discussed below). Some technologies (such as battery electric vehicles) have become more cost effective in recent years but widespread use will require the implementation of a suitable infrastructure and public acceptance of possible drawbacks (e.g. limited range and/or long recharge times).

The current paper deals with the implementation of a simple approach for understanding $\mathrm{CO}_{2}$ emissions. While the details of lifecycle analysis are not considered, the method does provide a quantitative technique for comparing the environmental impact of different transportation energy technologies. Battery electric vehicles (BEV's), fuel cell vehicles and hydrogen internal combustion engine $\left(\mathrm{H}_{2} \mathrm{ICE}\right)$ vehicles are compared with a traditional gasoline internal combustion engine vehicle in terms of expected $\mathrm{CO}_{2}$ emissions per kilometer. This analysis provides an appreciation for the factors that are relevant in assessing the environmental impact of different technologies and emphasizes that the common perception of environmentally friendly technologies can be misleading. It also provides a means for assessing the importance of electricity generating infrastructure in evaluating the carbon footprint of transportation methods. The significance of energy technologies that are prevalent in different countries is discussed.

\section{Analysis of $\mathrm{CO}_{2}$ Emissions}

The goal of the present analysis is to calculate the $\mathrm{CO}_{2}$ emissions per kilometer for different transportation technologies in an objective manner that allows for direct comparison of these technologies and provides the student 
with an understanding of the relevant factors in such an analysis. The mass of $\mathrm{CO}_{2}$ emitted per kilometer traveled may be expressed as

$$
\frac{\mathrm{kg}\left(\mathrm{CO}_{2}\right)}{\mathrm{km}}=\frac{\mathrm{kg}\left(\mathrm{CO}_{2}\right)}{\mathrm{E}_{\mathrm{p}}} \times \frac{\mathrm{E}_{\mathrm{p}}}{\mathrm{E}_{\mathrm{w}}} \times \frac{\mathrm{E}_{\mathrm{w}}}{\mathrm{km}}
$$

where $E$ is energy. The subscript "p" refers to primary energy and the subscript " $w$ " refers to energy delivered to the vehicle's wheels. The first term on the right hand side of the equation represents the amount of $\mathrm{CO}_{2}$ generated per unit of primary energy consumed (expressed in the present paper in MJ). The second term is the inverse of the conversion efficiency from primary energy to wheel energy. The final term on the right hand side is the average energy to the wheels needed to move the vehicle $1 \mathrm{~km}$. It is easy to see that the product of the terms on the right hand side of the equation will reduce to the expression on the left hand side. However, it is convenient to write the right hand side of the equation in this way as it illustrates the importance the various factors involved and provides a means of readily undertaking a quantitative analysis of $\mathrm{CO}_{2}$ emissions. In the case where different primary energy sources are used to ultimately provide energy for the same transportation technology, then Equation (1) can be written as a sum over the relevant sources as

$$
\frac{k g\left(\mathrm{CO}_{2}\right)}{k m}=\sum_{i} f_{i}\left[\frac{k g\left(\mathrm{CO}_{2}\right)}{E_{p}}\right]_{i}\left[\frac{E_{p}}{E_{w}}\right]_{i} \frac{E_{w}}{k m}
$$

where $f_{i}$ is the relative fraction of energy from a particular primary source. For example, equation (2) may be applied to a battery electric vehicle where the electricity use to charge the batteries comes from a variety of sources, e.g. coal, natural gas, nuclear, hydroelectric, etc. In this case there would be a term "i" in the sum for each of these primary sources. The conversion of primary energy to electricity is an important factor in determining the overall effectiveness of an energy infrastructure and has been the subject of a number of studies. Detailed analyses are important for a consideration of specific situations such as those presented for California by McCollum et al. (2012) and Poland by Budzianowski (2011).

The analysis presented in the current work does not consider the carbon footprint associated with vehicle manufacture and disposal or the infrastructure associated with fuel transportation or marketing, although these effects will tend to average out somewhat among the different technologies. The present analysis is, therefore, a reasonable comparison of different vehicle technologies and because of its simple and quantitative nature, it represents a useful pedagogical approach and gives students an understanding of the importance of an objective scientific analysis of the environmental aspects of non-fossil fuel energy. The analysis of the various terms on the right hand side of Equation (1) is considered below.

\subsection{Analysis of $\mathrm{kg}\left(\mathrm{CO}_{2}\right) /\left(E_{p}\right)$}

For a gasoline internal combustion engine (ICE) powered vehicle, gasoline is very close to a primary energy source, while for battery electric vehicles (BEV's) or hydrogen powered vehicles, the primary energy sources are first used to produce electricity, which is then stored for vehicle use. Thus $\operatorname{kg}\left(\mathrm{CO}_{2}\right) /\left(\mathrm{E}_{\mathrm{p}}\right)$ depends on the way in which electricity is produced, that is which primary energy sources are used. As an example, a rough breakdown of present electricity production in the U.S. is shown in Table 1.

Table 1. Breakdown of electricity production in the United States in 2011 as reported on the U.S. Energy Information Administration website (EIA, 2012)

\begin{tabular}{ll}
\hline fuel & \% U.S. electricity \\
\hline coal & 42.3 \\
natural gas $^{\text {b }}$ & 25.1 \\
petroleum $^{\mathrm{c}}$ & 0.7 \\
non-fossil fuel & 31.9
\end{tabular}

Notes: (a) does not include about $0 . \overline{2 \%}$ miscellaneous sources, (b) includes other fossil-fuel derived gases, (c) includes petroleum derived products.

The $\mathrm{CO}_{2}$ emission per unit energy (MJ) for different fossil fuels is obtained from an analysis of their energy content and is shown in Table 2. Budzianowski (2012) gives values of carbon emissions from primary energy 
sources as $24.5 \mathrm{~g}(\mathrm{C}) / \mathrm{MJ}$ [grams of carbon per $\mathrm{MJ}$ ] for coal/peat, $14.7 \mathrm{~g}(\mathrm{C}) / \mathrm{MJ}$ for natural gas and $17.5 \mathrm{~g}(\mathrm{C}) / \mathrm{MJ}$ for oil. These are equivalent (in units used in the present work) to $0.090 \mathrm{~kg}\left(\mathrm{CO}_{2}\right) / \mathrm{MJ}, 0.054 \mathrm{~kg}\left(\mathrm{CO}_{2}\right) / \mathrm{MJ}$ and 0.064 $\mathrm{kg}\left(\mathrm{CO}_{2}\right) / \mathrm{MJ}$, respectively. Given the variability in the chemical content of coal and heavy hydrocarbons, these literature values are consistent with the values presented in Table 2. The possible effect of carbon sequestration from fossil fuel generation is not considered and the $\mathrm{CO}_{2}$ emissions from non-fossil fuel sources (i.e. nuclear, hydroelectric and alternative energy sources) is considered to be zero, i.e. the term $\left[\mathrm{kg}\left(\mathrm{CO}_{2}\right) / \mathrm{E}_{\mathrm{p}}\right]_{\mathrm{i}}=0$ for nuclear, hydroelectric, etc. These assumptions will tend to cancel each other somewhat. While ignoring these factors will tend to present an overly optimistic view of non-fossil fuel energy, these effects are relatively small (at present), difficult to quantify and do not alter the basic conclusions of pedagogical value of the present approach.

Table 2. The $\mathrm{CO}_{2}$ emission per MJ for different fossil fuels

\begin{tabular}{ll}
\hline fossil fuel & $\mathbf{k g}\left(\mathbf{C O}_{2}\right) / \mathbf{E}_{\mathbf{p}}[\mathbf{k g} / \mathbf{M J}]$ \\
\hline carbon $(\sim$ coal $)$ & 0.11 \\
natural gas (methane, $\left.\mathrm{CH}_{4}\right)$ & 0.055 \\
heavy hydrocarbons $(>6 \mathrm{C} /$ molecule) & 0.069 \\
\hline
\end{tabular}

As $E_{p} / E_{w}$ is expected to be similar for all fossil fuel generated electricity (i.e. it is limited by the thermodynamic efficiency of a heat engine) it is suitable to use an average value of the $\mathrm{CO}_{2}$ emissions from these generating methods in Equation (2) and a corresponding total value of $f_{i}$ for fossil fuel generation. The average $\mathrm{kg}\left(\mathrm{CO}_{2}\right) / \mathrm{E}_{\mathrm{p}}$ is obtained from the values in Table 2 weighted by the percentages in Table 1. For fossil fuel generation of electricity in the U.S. as discussed above this analysis will give

$$
\begin{aligned}
<\mathrm{kg}\left(\mathrm{CO}_{2}\right) / \mathrm{E}_{\mathrm{p}}> & =0.11 \mathrm{~kg}\left(\mathrm{CO}_{2}\right) / \mathrm{MJ} \times(0.423) \\
& +0.055 \mathrm{~kg}\left(\mathrm{CO}_{2}\right) / \mathrm{MJ} \times(0.251) \\
& +0.069 \mathrm{~kg}\left(\mathrm{CO}_{2}\right) / \mathrm{MJ} \times(0.007) \\
& =0.061 \mathrm{~kg}\left(\mathrm{CO}_{2}\right) / \mathrm{MJ}
\end{aligned}
$$

This value is the appropriate average (for the United States) for all alternative energy vehicles that utilize electricity and a portable electricity storage mechanism (e.g. batteries or hydrogen). This calculation will, of course, be different for different locations worldwide as the distribution of primary energy sources used to produce electricity varies. National comparisons for some countries are discussed below.

\subsection{Analysis of $\left(E_{p}\right) /\left(E_{w}\right)$}

The quantity $\mathrm{E}_{\mathrm{p}} / \mathrm{E}_{\mathrm{w}}$ is a measure of the amount of primary energy needed to provide one unit of useable energy to the vehicle's wheels. It is the inverse of the overall efficiency (as a fraction) of the energy conversion processes involved and is given as

$$
\frac{E_{p}}{E_{w}}=\frac{100}{\text { efficiency }(\%)}
$$

There is often considerable uncertainty in estimating the efficiency of various energy conversion processes and there are, as well, indirect energy "costs", such as (e.g.) energy required for infrastructure development and fuel transportation. The estimates for the efficiency of the different energy conversion processes involved in converting primary energy to energy at the wheels for gasoline internal combustion vehicles and some alternative technologies are discussed below. The estimated efficiencies presented below are approximate values for the processes involved. More detailed analysis can include specific information about particular cases, e.g. specific vehicles, generating facilities, etc. if appropriate.

\subsubsection{Gasoline Internal Combustion Engine}

Table 3 gives the efficiency of the energy conversion process relevant to a gasoline internal combustion engine (ICE) vehicle. The efficiency of converting energy stored in gasoline to mechanical energy at the vehicle's wheels is limited by the thermodynamic efficiency of a heat engine. The value expressed in Table 3 is a typical net efficiency for an automobile engine. It is assumed that conversion of primary energy (i.e. crude oil) to gasoline has a high efficiency and gasoline can, therefore, be treated as a primary energy source. 
Table 3. Efficiency analysis for gasoline powered internal combustion engine vehicle showing net efficiency for conversion of primary energy (gasoline) to mechanical energy delivered to the vehicle's wheels

\begin{tabular}{ll}
\hline process & efficiency \\
\hline fossil fuel $\rightarrow$ mechanical & $17 \%$ \\
net efficiency & $\mathbf{1 7 \%}$ \\
\hline
\end{tabular}

\subsubsection{Battery Electric Vehicles}

The relevant efficiencies for a battery electric vehicle (BEV) using a fossil fuel primary energy source are shown in Table 4. The efficiency of primary energy to electricity is taken to be the average efficiency of a thermal generating station burning (e.g.) coal. Estimated efficiency for conversion of electrical energy to mechanical energy at the vehicle's wheels accounts for battery storage efficiency and electric motor efficiencies.

Table 4. Efficiency analysis for battery electric vehicle showing net efficiency for conversion of primary energy (fossil fuel) to mechanical energy delivered to the vehicle's wheels

\begin{tabular}{ll}
\hline process & efficiency \\
\hline fossil fuel $\rightarrow$ electricity & $40 \%$ \\
electricity $\rightarrow$ mechanical & $85 \%$ \\
net efficiency & $\mathbf{3 4 \%}$ \\
\hline
\end{tabular}

\subsubsection{Hydrogen Internal Combustion Engine}

Table 5 provides information about the typical route of hydrogen production and utilization for a hydrogen ICE. Hydrogen gas, at STP, is produced by electrolysis of water and is then compressed or liquefied for vehicle use. Internal combustion engine efficiency follows along the lines of the efficiency of a gasoline engine and is limited by thermodynamic factors.

Table 5. Efficiency analysis for hydrogen powered internal combustion engine vehicle showing net efficiency for conversion of primary energy (fossil fuel) to mechanical energy delivered to the vehicle's wheels. $\mathrm{CHG}=$ compressed hydrogen gas, $\mathrm{LH}_{2}=$ liquid hydrogen

\begin{tabular}{ll}
\hline process & efficiency \\
\hline fossil fuel $\rightarrow$ electricity & $40 \%$ \\
electricity $\rightarrow$ hydrogen gas & $70 \%$ \\
hydrogen gas $\rightarrow \mathrm{CHG} / \mathrm{LH}_{2}$ & $80 \%$ \\
$\mathrm{CHG} / \mathrm{LH}_{2} \rightarrow$ mechanical & $17 \%$ \\
net efficiency & $\mathbf{4 \%}$ \\
\hline
\end{tabular}

\subsubsection{Fuel Cell Vehicles}

The production and storage of hydrogen is described above. The efficiency of converting hydrogen to electricity (i.e. the fuel cell efficiency) is the efficiency of state-of-the art polymer electrolyte membrane (PEM) fuel cells which are typically most appropriate for vehicle use. Fuel cell vehicle efficiency is summarized in Table 6. 
Table 6. Efficiency analysis for hydrogen fuel cell powered vehicle showing net efficiency for conversion of primary energy (fossil fuel) to mechanical energy delivered to the vehicle's wheels

\begin{tabular}{ll}
\hline process & efficiency \\
\hline fossil fuel $\rightarrow$ electricity & $40 \%$ \\
electricity $\rightarrow$ hydrogen gas & 70 \\
hydrogen gas $\rightarrow$ CHG & 80 \\
CHG $\rightarrow$ electricity & 70 \\
electricity $\rightarrow$ mechanical & 90 \\
net efficiency & $\mathbf{1 4 \%}$ \\
\hline
\end{tabular}

\subsection{Analysis of $(M J)_{w} / \mathrm{km}$}

The energy per unit distance required for a vehicle can be determined on the basis of the characteristics of current gasoline powered vehicles. Specifically, the energy content of the fuel consumed per unit distance and the efficiency of the process are needed. In the case of the gasoline powered vehicle it is important to use the efficiency as presented in Table 3. In this case the gasoline powered vehicle efficiency will cancel out in Equation (2). Table 7 gives fuel consumption figures for a range of automobiles from major manufacturers. The values for mpg (miles per U.S. gallon) are combined city/highway figures as reported by the United States Environmental Protection Agency (2012). The fuel consumption in litres per $\mathrm{km}$ can be determined from the published values in mpg according to the conversion

$$
\frac{\text { litres }}{\mathrm{km}}=\frac{2.35(\text { litres } \times \mathrm{mpg} / \mathrm{km})}{\mathrm{mpg}}
$$

The energy requirement in MJ delivered to the wheels per km can be determined from the energy content of gasoline $34.8 \mathrm{MJ} /$ litre and the propulsion efficiency as

$$
\frac{\mathrm{E}_{\mathrm{w}}}{\mathrm{km}}=\frac{\text { litres }}{\mathrm{km}} \times \frac{\mathrm{MJ}}{\text { litre }} \times \text { efficiency }
$$

Calculated values for the various vehicles in Table 7 are given in the last column. These cover a range of values that is approximately a factor of 2 with an average around $0.55 \mathrm{MJ} / \mathrm{km}$ for a typical family sedan. This typical value will be used for further analysis, and Table 7 gives the range of values expected for different vehicles.

Table 7. U.S. Environmental Protection Agency (EPA) combined city/highway mileage ratings for selected 2012 automobiles with standard engine option and automatic transmission. The energy content of gasoline is $34.8 \mathrm{MJ}$ per litre and the average efficiency of an internal combustion engine was assumed to be $17 \%$. Values are calculated from data on the EPA website (EPA, 2012)

\begin{tabular}{llll}
\hline Vehicle (make/model) & $\mathbf{m p g}(\mathbf{U S})$ & litres/km & $\mathbf{E}_{\mathbf{w}} / \mathbf{k m ~}[\mathbf{M J} / \mathbf{k m}]$ \\
\hline smart fortwo & 36 & 0.065 & 0.39 \\
Chevrolet Sonic & 33 & 0.071 & 0.42 \\
Hyundai Sonata & 28 & 0.084 & 0.50 \\
Toyota Camry (V6) & 25 & 0.094 & 0.56 \\
BMW 535xi GT & 21 & 0.112 & 0.66 \\
Mercedes Benz S550 & 18 & 0.131 & 0.77 \\
\hline
\end{tabular}

\section{National Comparisons of $\mathrm{kg}\left(\mathrm{CO}_{2}\right) / \mathbf{k m}$}

The data as presented in the previous section can now be substituted into Equation (2) to calculate the $\mathrm{CO}_{2}$ emissions for the various transportation technologies discussed here. For the electricity generating technologies in current use in the United States the calculated values of $\mathrm{kg}\left(\mathrm{CO}_{2}\right) / \mathrm{km}$ are given in Table 8 . 
Table 8. Calculated values for the $\mathrm{CO}_{2}$ emission per $\mathrm{km}$ for different transportation technologies in the United States

\begin{tabular}{lllll}
\hline Technology & $<\mathbf{k g}\left(\mathbf{C O}_{2}\right) / \mathbf{E}_{\mathbf{p}}>[\mathbf{k g} / \mathbf{M J}]$ & $\mathbf{E}_{\mathbf{p}} / \mathbf{E}_{\mathbf{w}}$ & $\mathbf{E}_{\mathbf{w}} / \mathbf{k m}[\mathbf{M J} / \mathbf{k m}]$ & $\mathbf{k g}\left(\mathbf{C O}_{2}\right) / \mathbf{k m}$ \\
\hline gasoline ICE & 0.069 & 5.9 & 0.55 & 0.22 \\
BEV & 0.061 & 2.9 & 0.55 & 0.097 \\
$\mathrm{H}_{2}$ ICE & 0.061 & 25 & 0.55 & 0.83 \\
$\mathrm{H}_{2}$ fuel cell & 0.061 & 7.1 & 0.55 & 0.24 \\
\hline
\end{tabular}

This analysis shows that the net environmental impact of battery electric vehicles in the United States is quite positive (compared with gasoline vehicles). Fuel cell vehicles are about neutral, while $\mathrm{H}_{2}$ internal combustion engine vehicles have a very negative environmental effect. Improvements to the environmental impact of alternative fuel vehicles can be made by increasing energy conversion efficiencies (i.e. decreasing $\mathrm{E}_{\mathrm{p}} / \mathrm{E}_{\mathrm{w}}$ and increasing vehicle efficiencies (i.e. decreasing $\mathrm{E}_{\mathrm{w}} / \mathrm{km}$ ). However, it is through the shift in electricity generating technology away from fossil fuels (i.e. the reduction of $<\operatorname{kg}\left(\mathrm{CO}_{2}\right) / \mathrm{E}_{\mathrm{p}}>$ ), that the most substantial improvements can be made.

The effects of electric generating technology that is prevalent in certain countries are illustrated in Table 9. The factor $<\mathrm{kg}\left(\mathrm{CO}_{2}\right) / \mathrm{E}_{\mathrm{p}}>$ is a multiplicative factor in Equation (2) for alternative fuel vehicles and the resulting $\mathrm{kg}\left(\mathrm{CO}_{2}\right) / \mathrm{km}$ values scale correspondingly. The value for the world average as calculated in the present work $\left(0.060 \mathrm{~kg}\left(\mathrm{CO}_{2}\right) / \mathrm{MJ}\right)$ is consistent with the analysis of world primary energy consumption as presented by the International Energy Agency (IEA, 2011) which gives an average of $15.4 \mathrm{~g}(\mathrm{C}) / \mathrm{MJ}$ (or $\left.0.056 \mathrm{~kg}\left(\mathrm{CO}_{2}\right) / \mathrm{MJ}\right)$. While the world average is essentially identical to the value for the United States, some countries have energy policies that make electricity production more environmentally advantageous. This is directly a result of the lower than (worldwide) average of fossil fuels used in electricity generation. Two examples are clearly identifiable in Table 9, Canada and France, where electricity is produced primarily by $\mathrm{CO}_{2}$-free methods; hydroelectricity and nuclear energy, respectively. In Canada there is a reduction of about a factor of 3 in $\mathrm{kg}\left(\mathrm{CO}_{2}\right) / \mathrm{km}$ production for alternative fuel vehicles compared with the U.S. for the same type of alternative technology vehicle. In France there is about a factor of 8 reduction. This means that in Canada BEV's and fuel cell vehicles are clearly advantageous over gasoline vehicles and in France even $\mathrm{H}_{2}$ ICE vehicles come out ahead of gasoline ICE vehicles in net $\mathrm{CO}_{2}$ emissions. Thus it is clear that, at least from a greenhouse gas emissions standpoint, alternative transportation technologies are more environmentally attractive in certain countries.

Table 9. National comparisons for some countries and world average for electricity production for 2008 from the International Energy Agency website (IEA, 2012). Calculated values of the average $<\operatorname{kg}\left(\mathrm{CO}_{2}\right) / \mathrm{E}_{\mathrm{p}}>$ as described above for alternative fuel vehicles are shown

\begin{tabular}{lllllll}
\hline nation & coal & $\begin{array}{l}\text { natural } \\
\text { gas }\end{array}$ & petroleum & non-fossil fuels & $\begin{array}{l}\text { principal non-fossil } \\
\text { fuel type }\end{array}$ & $<\mathrm{kg}\left(\mathrm{CO}_{2}\right) / \mathrm{E}_{\mathrm{p}}>[\mathrm{kg} / \mathrm{MJ}]$ \\
\hline Australia & 77.0 & 15.2 & 1.1 & 6.7 & hydroelectric & 0.094 \\
Canada & 17.2 & 6.4 & 1.5 & 74.9 & hydroelectric & 0.023 \\
China & 79.1 & 0.9 & 0.7 & 13.0 & hydroelectric & 0.088 \\
France & 4.7 & 3.8 & 1.0 & 90.5 & nuclear & 0.008 \\
Germany & 45.7 & 13.8 & 1.4 & 39.1 & nuclear & 0.059 \\
India & 68.6 & 9.9 & 4.1 & 17.4 & hydroelectric & 0.084 \\
Japan & 26.6 & 26.2 & 12.8 & 34.4 & nuclear & 0.052 \\
U.K & 32.6 & 45.5 & 1.6 & 20.3 & nuclear & 0.062 \\
World & 41.0 & 21.0 & 5.5 & 32.5 & hydroelectric & 0.060 \\
average & & & & & &
\end{tabular}




\section{Conclusions}

The environmental aspects of energy use are an important consideration and the viability of pursuing alternative technologies which have more serious environmental consequences than traditional fossil fuel technology is questionable, at least in the short term. The simple analysis presented in the current work shows that in the United States that the average $\mathrm{CO}_{2}$ emissions for BEV's, $\mathrm{H}_{2}$ ICE vehicles and $\mathrm{H}_{2}$ fuel cell vehicles are $0.097 \mathrm{~kg}\left(\mathrm{CO}_{2}\right) / \mathrm{km}$, $0.83 \mathrm{~kg}\left(\mathrm{CO}_{2}\right) / \mathrm{km}$ and $0.24 \mathrm{~kg}\left(\mathrm{CO}_{2}\right) / \mathrm{km}$, respectively, compared with $0.22 \mathrm{~kg}\left(\mathrm{CO}_{2}\right) / \mathrm{km}$ for a conventional gasoline ICE vehicle. The average situation world wide is shown to be essentially the same as in the United States and shows that overall BEV's provide a clear environmental advantage, fuel cell vehicles are about neutral and $\mathrm{H}_{2}$ ICE vehicles are environmentally counterproductive. It is clear that the current advantages of alternative energy for transportation purposes is directly related to electric generating methods and improvements in the carbon foot print of this infrastructure in most parts of the world would improve the attractiveness of alternative transportation technologies. The desirability of different energy technologies must also be considered on the basis of economic factors and resource availability factors but a positive environmental impact is a necessary condition for viability. A quantitative analysis of $\mathrm{CO}_{2}$ emissions is typically not a component of the literature that most likely forms public opinion (see e.g. discussion of hydrogen vehicles by Transport Canada, 2012).

The present paper presents an objective method of analyzing the environmental impact (in terms of $\mathrm{CO}_{2}$ emissions) for BEV's, fuel cell vehicles and $\mathrm{H}_{2}$ ICE vehicles in comparison with traditional gasoline powered vehicles. This analysis provides a quantitative approach to understanding this problem that is based on sound physical principles and emphasizes the need for such a quantitative evaluation of the carbon footprint of alternative energy technologies. Given the popularity of sustainable energy related courses in university science and engineering faculties, such a quantitative approach can supplement discussions of alternative transportation technologies and provide students with an appreciation of the complexity of a thorough objective analysis.

\section{References}

Budzianowski, W. M. (2011). Can 'negative net $\mathrm{CO}_{2}$ emissions' from decarbonised biogas-to-electricity contribute to solving Poland's carbon capture and sequestration dilemmas? Energy, 36, 6318-6325. http://dx.doi.org.ezproxy.library.dal.ca/10.1016/j.energy.2011.09.047

Budzianowski, W. M. (2012). Target for national carbon intensity of energy by 2050: A case study of Poland's energy system. Energy, 46, 575-581. http://dx.doi.org.ezproxy.library.dal.ca/10.1016/j.energy.2012.07.051

EIA. (2012). U.S. Energy Information Administration. Retrieved September 26, 2012, from http://www.eia.gov/electricity/monthly/epm_table_grapher.cfm?t=epmt_1_1

EPA. (2012). Environmental Protection Agency. Retrieved September 26, 2012, from http://www.fueleconomy.gov/feg/Find.do?action=sbsSelect

IEA. (2011). Key World Energy Statistics. Retrieved from http://www.iea.org/publications/freepublications/publication/key_world_energy_stats-1.pdf

IEA. (2012). International Energy Agency. Retrieved September 26, 2012, from http://www.iea.org/stats/index.asp

Korchinski, W. J. (2007). Are hydrogen cars good for America? Reason Foundation, Policy Study 363. Retrieved from http://reason.org/files/87189798b5d1d8ce1be8fb811a21a3d0.pdf

Kraushaar, J. A., \& Ristinen, R. A. (1993). Energy and Problems of a Technical Society (2nd ed.). New York: Wiley.

Kruger, P. (2006). Alternative Energy Resources: The Quest for Sustainable Energy. Hoboken: Wiley.

McCollum, D., Yang, C., Yeh, S., \& Ogden, J. (2012). Deep greenhouse gas reductions scenarios for California strategic implications from the CA-TIMES energy economic systems model. Energy Strategy Reviews, 1, 19-32. http://dx.doi.org/10.1016/j.esr.2011.12.003

$\begin{array}{llllll}\text { Transport } \quad \text { Canada. } & \text { (2012). Retrieved } & \text { October } & 19, & \text { 2012, }\end{array}$ http://www.tc.gc.ca/eng/programs/environment-etv-videos-hydrogen-eng-1954.htm

Vanek, F. M., \& Albright, L. D. (2008). Energy Systems Engineering: Evaluation and Implementation. New York: McGraw Hill. 